\title{
ANALISIS GEOGRAFIS KONSENTRASI INDUSTRI KULIT DI KABUPATEN GARUT
}

\author{
Bagja Waluya $^{1)}$; Citra Adhitya ${ }^{2)}$ \\ syi_ak@yahoo.com \\ 1) Alumni Jurusan Pendidikan Geografi FPIPS UPI Tahun 2010 \\ ${ }^{2)}$ Jurusan Pendidikan Geografi FPIPS UPI
}

\begin{abstract}
ABSTRAK
Persebaran industri termasuk ke dalam proses yang selektif, dimana ada faktor-faktor yang perlu dipertimbangkan dalam membentuk suatu pola persebaran industri. Secara geografis, keberadaan industri-industri kulit di Kabupaten Garut cenderung terkonsentrasi dua kecamatan, yaitu di Kecamatan Garut Kota dan Karangpawitan. Berdasarkan fenomena tersebut maka permasalahan penelitian difokuskan pada analisis faktor-faktor geografis pada konsentrasi Industri Kulit di Kabupaten Garut. Tujuan penelitian ini adalah sbb: 1) mendeskripsikan pola konsentrasi industri barang kerajinan kulit; 2) memperoleh gambaran mengenai ketersediaan bahan baku dan pengaruhnya terhadap lokasi industri barang kerajinan kulit; 3) memperoleh gambaran mengenai ketersediaan tenaga kerja dan pengaruhnya terhadap lokasi industri barang kerajinan kulit; dan 4) mendeskripsikan daerah-daerah pemasaran dan pengaruhnya terhadap lokasi industri barang kerajinan kulit di Kabupaten Garut. Metode penelitian yang digunakan adalah metode deskriprif. Sampel penelitian terdiri dari 20 pengusaha, 75 tenaga kerja dan 100 diambil dari masyarakat yang bukan pengrajin kulit. Hasil penelitian menunjukkan bahwa pola konsentrasi industri barang kerajinan kulit di Kabupaten Garut bersifat mengelompok dengan nilai indeks tetangga terdekat sebesar 0,69199842. Konsentrasi industri kulit sangat dipengaruhi oleh faktor bahan baku yang tersedia di kawasan Sukaregang dengan tingkat korelasi sebesar 0,473, menghubungkan antara ketersediaan bahan baku dengan lokasi industri yang ada di Kota Wetan, Karangmulya dan Lebak Agung. Lokasi industri tidak terlalu berpengaruh terhadap ketersediaan tenaga kerja. Hal ini diperkuat dengan hubungan antar variabel tersebut sebesar 0,245 yang menunjukkan pola hubungan yang lemah. Dalam hal pemasaran produk kerajinan kulit banyak dipasarkan ke kotakota luar provinsi. Berdasarkan hal tersebut maka didapat nilai korelasi sebesar 0,226 antara daerah pemasaran dengan lokasi industri.
\end{abstract}

Kata kunci: lokasi industri, pola konsentrasi, industri kerajinan kulit.

\section{PENDAHULUAN}

\section{Latar Belakang}

Perindustrian di suatu daerah dapat dianalisis secara geografis. Ciri paling mencolok dari aktivitas ekonomi secara geografis adalah faktor lokasi, termasuk di dalamnya menyangkut hal konsentrasi, ketimpangan dan persebaran. Persebaran 
industri termasuk ke dalam proses yang selektif, dimana ada faktor-faktor yang perlu dipertimbangkan dalam membentuk suatu pola persebaran industri. Menurut Daldjoeni (1998:167) bahwa "faktor lokasi yang mempengaruhi keberadaan industri diantaranya wilayah bahan mentah, pasaran, sumber suplai tenaga kerja, wilayah bahan bakar (tenaga), jalur transportasi, serta penjaluran atau zoning kota."

Kegiatan sektor industri di Kabupaten Garut sangat beranekaragam. Industri tersebut meliputi industri penyamakan kulit, jaket kulit, industri batik, sutera alam, dodol, minyak akar wangi dan industri kerajinan anyaman bambu. Dari berbagai komoditas yang ada, tercatat beberapa diantaranya telah menembus pasar ekspor seperti: teh hitam, teh hijau, karet, bulu mata palsu, minyak akar wangi, jaket kulit, kulit tersamak dan kain sutera.

Salah industri yang terkenal di Kabupaten Garut adalah industri penyamakan kulit. Eksistensi industri selama ini telah menumbuhkan berbagai industri kecil yang terkait dengan industri penyamakan kulit sebagai industri utama. Industri-industri kecil tersebut antara lain yang memproduksi jaket kulit, tas, sepatu, sarung tangan dan aksesoris lainnya yang berbahan dasar kulit.

Industri kulit merupakan industri dengan jumlah terbesar di Kabupaten Garut. Selain itu industri ini merupakan sektor utama dalam penyerapan tenaga kerja dibandingkan dengan sektor lainnya. Walau demikian, keberadaannya cenderung terkonsentrasi di Kecamatan Garut Kota dan Karangpawitan. Menurut Weber dalam Kuncoro (2001:2) bahwa "konsentrasi industri muncul terutama untuk minimisasi biaya transpor atau biaya produksi". Berdasarkan latar belakang tersebut, maka rumusan masalah penelitiannya adalah Bagaimana faktor-faktor geografis mempengaruhi lokasi industri barang kerajinan kulit di Kabupaten Garut?

\section{Tujuan}

Tujuan yang hendak dicapai dalam penelitian ini adalah: 1) mendeskripsikan pola konsentrasi industri barang kerajinan kulit; 2) memperoleh gambaran mengenai ketersediaan bahan baku dan pengaruhnya terhadap lokasi industri barang kerajinan kulit; 3) memperoleh gambaran mengenai ketersediaan tenaga kerja dan pengaruhnya terhadap lokasi industri barang kerajinan kulit; dan 4) mendeskripsikan daerah-daerah pemasaran dan pengaruhnya terhadap lokasi industri barang kerajinan kulit di Kabupaten Garut.

\section{METODE PENELITIAN}

Metode penelitian yang digunakan dalam penelitian ini yaitu metode penelitian deskriprif. Teknik pengumpulan data dilakukan melalui teknik observasi, wawancara, studi dokumentasi, dan literatur. Jumlah populasi adalah seluruh industri barang kerajinan kulit yang ada di Kabupaten Garut termasuk para pekerjanya, meliputi dua kecamatan yaitu Kecamatan Karangpawitan dan Kecamatan Garut Kota. Sedangkan sampel penelitian terdiri dari 20 pengusaha, 75 tenaga kerja dan 100 diambil dari masyarakat yang bukan pengrajin kulit. 
Tahap pengolahan dan analisis data meliputi dua tahap yaitu tahap analisis kualitatif dan tahap analisis kuantitatif. Untuk mengetahui kecenderungan jawaban responden dan fenomena di lapangan digunakan persentase dan uji korelasi. Sedangkan pola konsentrasi industri kulit di Kabupeten Garut dikaji dengan mengunakan analisa tetangga terdekat.

\section{HASIL DAN PEMBAHASAN}

\section{Kondisi Geografis Kabupaten Garut}

Kabupaten Garut mempunyai luas wilayah sekitar $3.066,88 \mathrm{~km}^{2}$. Secara geografis terletak diantara $6^{0} 57^{\prime} 34^{\prime \prime}-7^{0} 44^{\prime} 57^{\prime \prime}$ Lintang Selatan dan $107^{0} 24^{\prime} 3^{\prime \prime}$ $108^{0} 24^{\prime} 34^{\prime \prime}$ Bujur Timur dengan batas-batas wilayah : sebelah utara berbatasan dengan Kabupaten Bandung dan Kabupaten Sumedang; sebelah timur berbatasan dengan Kabupaten Tasikmalaya; sebelah selatan berbatasan dengan Samudera Indonesia; dan sebelah barat berbatasan dengan Kabupaten Bandung dan Kabupaten Cianjur. Kabupaten Garut terbagi menjadi 42 Kecamatan. Adapun Kecamatan yang menjadi lokasi penelitian industri kulit di Kabupaten Garut yaitu Kecamatan Karangpawitan dan Garut Kota.

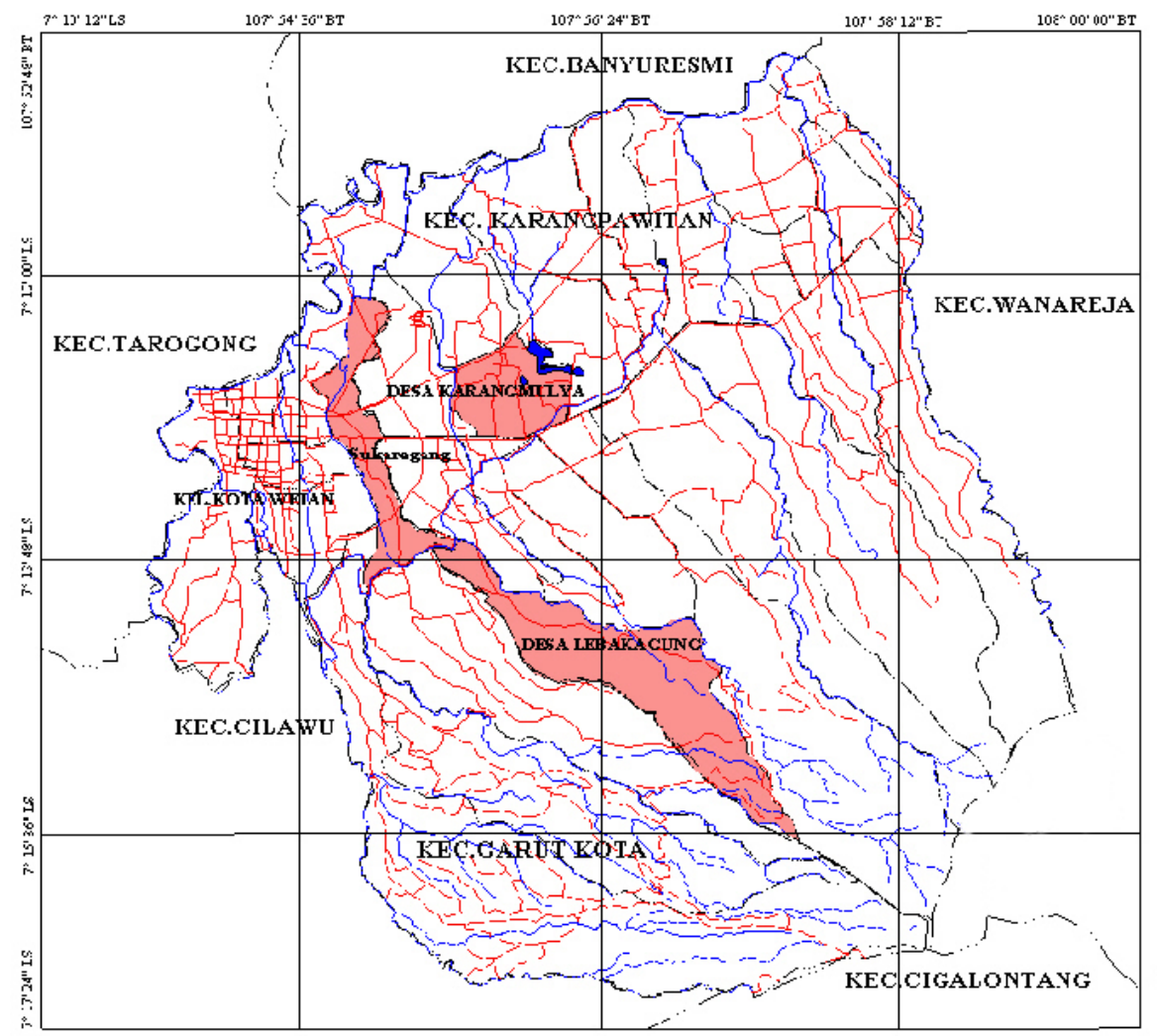

Gambar 1. Peta Wilayah Penelitian 
Penduduk di Kabupaten Garut pada tahun 2008 berjumlah 2.274.973 jiwa dengan jumlah rumahtangga 568.608 dan tingkat kepadatannya 742 jiwa $/ \mathrm{km}^{2}$ atau sangat padat. Walau demikian, persebaran penduduknya tidak merata di seluruh wilyah kecamatan yang ada melainkan hanya di pusat kota saja seperti di Kecamatan Garut Kota. Mata pencaharian penduduk di Kabupaten Garut sangat didominasi oleh sektor pertanian, mengingat potensi lahan yang masih sangat luas dan subur untuk terlaksananya kegiatan ekonomi tersebut. Sedangkan yang bergerak pada sektor industri, termasuk di dalamnya industri penyamakan kulit masih sangat sedikit.

\section{Keberadaan Industri Kulit di Kabupaten Garut}

\section{a. Bahan Baku}

Daerah sumber bahan baku utama bagi industri barang kerajinan kulit yaitu Sukaregang merupakan salah satu daerah di Kelurahan Kota Wetan, Kecamatan Garut Kota. Sukaregang ini merupakan pusat bahan baku kulit yang sudah mengalami penyamakan. Selain itu ada sebagian pengusaha yang mengambil bahan baku kulit dari daerah lain. Adapun daerah sumber bahan baku kulit yang diambil oleh sampel pengrajin kulit yang berada di Kota Wetan, Karangmulya, dan Lebak Agung dapat dilihat pada tabel 1 .

Tabel 1. Daerah Sumber Bahan Baku Kulit

\begin{tabular}{ccc}
\hline Daerah Asal Bahan Baku & F & \% \\
\hline Sukaregang & 12 & 60 \\
\hline Sukaregang dan Tanjungpura & 2 & 10 \\
\hline Sukaregang \& Rawa & 1 & 5 \\
\hline Sukaregang \& Jakarta & 2 & 10 \\
\hline Jakarta, Tangerang, Bekasi & 3 & 15 \\
\hline Total & $\mathbf{2 0}$ & $\mathbf{1 0 0}$ \\
\hline
\end{tabular}

Sumber: Hasil Penelitian 2009

Jumlah bahan baku yang terdapat di daerah sumber bahan baku ada yang cukup memenuhi proses produksi maupun tidak. Sebagian besar pemilik industri kulit di Kelurahan Kota Wetan memiliki ketersediaan bahan baku yang banyak karena dipasok dari Sukaregang. Berdeda dengan ketersediaan bahan baku bagi pengrajin kulit di Karangmulya yang relatif sedikit karena mendatangkan bahan baku dari luar kota seperti Jakarta, Tangerang dan Bekasi. Sedangkan pengrajin yang berada di Lebak Agung ketersediaan bahan baku relatif banyak karena kedekatan lokasinya dengan Sukaregang sebagai pusat bahan baku.

Jarak lokasi bahan baku ke lokasi produksi berbeda-beda dari tiap wilayah sampel penelitian. Jarak sumber bahan baku ke lokasi produksi dapat berpengaruh terhadap biaya pengambilan bahan baku. Jarak lokasi bahan baku kulit terdekat yaitu terletak di daerah Kelurahan Kota Wetan dengan jarak < 500 meter dari Sukaregang. Hal ini berarti, industri yang berlokasi di Kota Wetan mendapatkan bahan baku dengan jarak terdekat. Sedangkan pengrajin yang berada di Karangmulya sebagian besar 
mendatangkan bahan baku yang berasal dari luar kota, sehingga jarak lokasi bahan baku dengan tempat produksi relatif jauh. Pengambilan bahan baku pada umumnya melalui perantara. Sebagian besar pengrajin kulit yang ada di Lebak Agung membeli bahan baku di Sukaregang, Garut Kota sehingga jarak yang ditempuh berkisar antara $1-2 \mathrm{~km}$.

Industri barang kerajinan kulit di Kabupaten Garut tersebar di dua kecamatan yaitu Kecamatan Garut Kota dan Karangpawitan. Dari kedua kecamatan tersebut industri barang kerajinan kulit dapat ditemukan dari beberapa desa. Adapun lokasi industri barang kerajinan kulit di wilayah sampel penelitian dapat dilihat pada tabel 2.

Tabel 2. Lokasi Industri Barang Kerajinan Kulit

\begin{tabular}{clcc}
\hline No. & \multicolumn{1}{c}{ Lokasi Industri } & F & $\%$ \\
\hline 1 & Sukaregang, Kel.Kota Wetan & 12 & 60 \\
\hline 2 & Karangtengah, Desa Karangmulya & 2 & 10 \\
\hline 3 & Cibangban, Desa Karangmulya & 3 & 15 \\
\hline 4 & Desa Lebak Agung & 3 & 15 \\
\hline \multicolumn{2}{c}{ Jumlah } & 20 & 100 \\
\hline
\end{tabular}

Sumber: Hasil Penelitian 2009

Industri barang kerajinan kulit banyak ditemukan di daerah Sukaregang agar berdekatan lokasinya dengan sumber bahan baku yaitu penyamakan kulit. Hal ini tentu akan berdampak pada biaya angkut bahan baku yang paling rendah dibandingkan dengan industri-industri yang lokasinya jauh dari sumber bahan baku atau harus mendatangkan dari daerah lain (Tabel 3).

Tabel 3. Ongkos Rata-rata Bahan Baku Perminggu

\begin{tabular}{|c|c|c|c|c|c|c|c|}
\hline \multirow[t]{2}{*}{ No } & \multirow{2}{*}{$\begin{array}{c}\text { Ongkos Bahan } \\
\text { baku }\end{array}$} & \multicolumn{2}{|c|}{ Kota Wetan } & \multicolumn{2}{|c|}{ Karangmulya } & \multicolumn{2}{|c|}{ Lebak Agung } \\
\hline & & $\mathbf{F}$ & $\%$ & $\mathbf{F}$ & $\%$ & $\mathbf{F}$ & $\%$ \\
\hline 1 & 0 & 4 & 33,3 & 1 & 20 & & \\
\hline 2 & $10.000-25.000$ & 6 & 50 & & & 2 & 66,7 \\
\hline 3 & $26.000-50.000$ & 2 & 16,7 & 4 & 80 & & \\
\hline 4 & $>50.000$ & & & & & 1 & 33,3 \\
\hline & Jumlah & 12 & 100 & 5 & 100 & 3 & 100 \\
\hline
\end{tabular}

Sumber: Hasil Penelitian 2009

\section{b. Tenaga Kerja}

Pada umumnya tenaga kerja berasal dari lingkungan sekitar dimana industri itu didirikan. Tenaga kerja bisa berasal dari desa yang sama dengan lokasi industri atau desa lain yang berdekatan dengan lokasi industri. Adapun daerah asal tenaga kerja dapat dilihat pada tabel 4 .

Tabel 4. Daerah Asal Tenaga Kerja

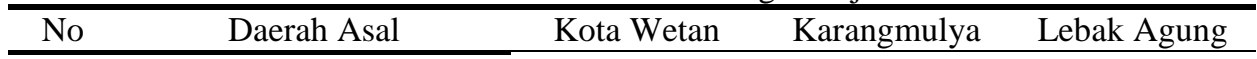




\begin{tabular}{llcccccc}
\hline & Tenaga Kerja & $\mathrm{F}$ & $\%$ & $\mathrm{~F}$ & $\%$ & $\mathrm{~F}$ & $\%$ \\
\hline 1. & Sukaregang & 27 & 54 & & & & \\
\hline 2. & Gagak Lumayung & 8 & 16 & & & & \\
\hline 3. & Lengkong Jaya & 2 & 4 & 3 & 20 & & \\
\hline 4. & Cimasuk & 4 & 8 & & & & \\
\hline 5. & Suci & 9 & 18 & & & 2 & 20 \\
\hline 6. & Karangmulya & & & 6 & 40 & & \\
\hline 7. & Karang Tengah & & & 4 & 26,7 & & \\
\hline 8. & Cibangban & & & 2 & 13,3 & & \\
\hline 9. & Lebak Agung & & & & & 8 & 80 \\
\hline & Jumlah & 50 & 100 & 15 & 100 & 10 & 100 \\
\hline
\end{tabular}

Sumber: Hasil Penelitian 2009

Berdasarkan hasil penelitian bahwa sebagian besar tenaga kerja berasal dari daerah sekitar di mana lokasi industri kerajinan kulit berada, yaitu Sukaregang. Adapula tenaga kerja yang berasal dari desa lain seperti Suci, Cimasuk, dan Lebak Agung. Ketiga desa ini relatif dekat namun berbeda kecamatan. Tiga daerah tersebut masuk ke dalam wilayah kecamatan Karangpawitan. Desa lainnya yang merupakan asal tenaga kerja kulit yaitu Desa Karangmulya tepatnya berada di daerah Cibangban dan Karangtengah.

Ketersediaan tenaga kerja di setiap sampel wilayah penelitian berbeda-beda. Pada umumnya tenaga kerja berasal dari lingkungan sekitar, yaitu di Kota Wetan memiliki tingkat ketersediaan yang banyak. Hal ini disebabkan karena faktor jumlah dan kepadatan penduduk yang relatif tinggi di daerah tersebut sehingga banyak tenaga kerja yang diserap dari daerah lingkungan sekitar. Sebagian kecil dari pengusaha berasumsi bahwa ketersediaan tenaga kerja sedikit. Hal ini terjadi jika tingkat permintaan konsumen meningkat tetapi produksi tetap dikarenakan jumlah pekerja yang bekerja tetap, sehingga terjadi kekurangan tenaga kerja untuk memenuhi permintaan tersebut. Biasanya kondisi ini terjadi dalam periode waktu tertentu jika ada permintaan pesanan yang meningkat.

Ketersediaan tenaga kerja di Lebak Agung relatif banyak. Sebagian pengusahanya mempekerjakan tenaga kerja yang berasal dari lingkungan sekitar dan anggota keluarganya. Sedangkan sebagian besar pengusaha yang ada di Karangmulya mengatakan bahwa ketersediaan tenaga kerja banyak dan sebagian lagi mengatakan cukup. Hal ini dikarenakan jumlah penduduk yang berada di daerah Karangmulya tidak sebanyak dengan yang ada di Kota Wetan. Di daerah Karangmulya banyak tenaga kerja yang memiliki tingkatan usia non produktif atau usia dibawah umur untuk dijadikan sebagai pekerja. Adapun tingkat ketersediaan tenaga kerja dapat dilihat pada tabel 5 .

Tabel 5. Ketersediaan Tenaga Kerja

\begin{tabular}{cccccccc}
\hline \multirow{2}{*}{ No. } & Ketersediaan Tenaga Kerja & \multicolumn{2}{c}{ Kota Wetan } & \multicolumn{2}{c}{ Karang Mulya } & \multicolumn{2}{c}{ Lebak Agung } \\
\cline { 3 - 8 } & & F & $\%$ & F & $\%$ & F & $\%$ \\
\hline 1. & Banyak & 7 & 58,3 & 2 & 40 & 2 & 66,7 \\
\hline
\end{tabular}




\begin{tabular}{llcccccc}
\hline 2. & Cukup & 3 & 25 & 3 & 60 & 1 & 33,3 \\
\hline 3. & Sedikit & 2 & 16,7 & & & & \\
\hline & Jumlah & 12 & 100 & 5 & 100 & 3 & 100 \\
\hline
\end{tabular}

Sumber: Hasil Penelitian 2009

Kedekatan lokasi usaha dengan tempat tinggal tenaga kerja mengakibatkan rendahnya biaya transport yang harus dikeluarkan setiap harinya, bahkan sebagian besar para pekerja di industri kerajinan kulit tidak mengeluarkan biaya transport. Jarak para pekerja dengan lokasi industri sebagian besar berjarak < 500m. Dengan demikian, berjalan kaki merupakan kebiasaan mereka pergi ke tempat kerjanya.

Menurut Teori Lokasi Least Labour Cost Location yang dikemukakan Weber, bahwa "kawasan yang berisi tenaga kerja murah dapat menjadi alasan untuk berdirinya pabrik di situ". Pembagian upah yang diterima oleh tenaga kerja yang ada di Kota Wetan bervariatif dari segi nominal. Hal ini disebabkan karena bidang pekerjaan tenaga kerja yang ada di daerah tersebut cukup bervariatif. Bidang pekerjaannya mencakup pengrajin jaket kulit, sarung tangan, sepatu maupun aksesoris kulit lainnya. Pada umumnya upah yang diterima tenaga kerja yang memproduksi jaket kulit dan sepatu akan lebih tinggi bila dibandingkan dengan upah yang diterima oleh tenaga kerja yang menghasilkan sarung tangan. Sedangkan di Karangmulya sebagian besar tenaga kerja menerima upah berkisar antara 150.000 200.000 dan 210.000 - 250.000. Ini berarti upah yang diterima tenaga kerja yang ada di Karangmulya relatif lebih kecil bila dibandingkan dengan upah yang diterima oleh tenaga kerja yang ada di Kota Wetan. Hal ini disebabkan karena tenaga kerja yang ada di Karangmulya sebagian besar hanya memproduksi barang-barang kerajinan kulit skala kecil seperti tas tangan, tempat HP maupun aksesoris kulit lainnya. Sementara itu, di Lebak Agung, upah yang diterima relatif lebih besar bila dibandingkan dengan daerah Kota Wetan dan Karangmulya karena sebagian besar tenaga kerja menerima upah dengan jumlah nominal > 250.000.

\section{c. Pemasaran}

Barang kerajinan kulit yang sudah diproduksi kemudian dipasarkan. Sebagian besar daerah pemasarannya masih bersifat lokal dan regional, yaitu dipasarkan di toko-toko kerajinan kulit yang ada di sepanjang jalan Sukaregang maupun dengan melakukan pengiriman ke kota-kota besar yang ada di Pulau Jawa. Sedangkan pemasaran yang dilakukan pada skala nasional maupun internasional masih terbatas.

Tabel 6. Daerah Pemasaran Barang Kerajinan Kulit

\begin{tabular}{ccc}
\hline No & Jenis Produk & Daerah Pemasaran \\
\hline 1. & Jaket Kulit & Sukaregang, Bandung, Jakarta \\
\hline 2. & Sepatu dan Sandal & Sukaregang, Jakarta, Tangerang, Bekasi, Cilacap, \\
& Kulit & Cilegon, Yogyakarta \\
\hline 3. & Sarung Tangan Kulit & $\begin{array}{c}\text { Sukaregang, Tasik, Bandung, Jakarta, Bekasi, Malang, } \\
\text { Cilacap, Cilegon, Semarang, Surabaya }\end{array}$ \\
\hline
\end{tabular}




\begin{tabular}{|c|c|c|}
\hline 4. & Aksesoris Kulit & $\begin{array}{l}\text { Sukaregang, Tasik, Bandung, Jakarta, Bekasi, } \\
\text { Karawang, Merak (Banten), Yogyakarta, Surabaya }\end{array}$ \\
\hline
\end{tabular}

Sumber: Hasil Penelitian 2009

Berdasarkan hasil penelitian diketahui bahwa jangkauan pemasaran barang kerajinan kulit sebagian besar meliputi daerah luar propinsi. Pada umumnya dipasarkan di Jabotabek, Yogyakarta, daerah sekitar Jawa Tengah maupun Jawa Timur. Jangkauan barang kerajinan kulit yang mulai meluas dari waktu ke waktu disebabkan oleh semakin banyaknya permintaan barang dari berbagai kota. Kondisi tersebut menambah panjangnya mata rantai pemasaran dari pihak produsen hingga sampai ke tangan beberapa distributor yang menyalurkan produk hingga sampai ke tangan konsumen. Besar kecilnya biaya pemasaran tentunya sangat bergantung pada jarak daerah pemasaran dengan sumber produksi serta jenis sarana angkutan yang tersedia. Pemilik usaha yang ada di Kota Wetan mengeluarkan ongkos pemasaran yang paling tinggi dikarenakan harus memasarkan sendiri. Berbeda halnya dengan pengrajin yang ada di Karangmulya, meskipun memilki daerah tujuan pemasaran yang cukup jauh tetapi mengeluarkan biaya pemasaran yang lebih sedikit. Hal ini disebabkan karena pemasaran dari produk yang dihasilkan oleh pemilik usaha yang ada di Karangmulya sebagian besar dilakukan oleh pemborong atau distributor yang berasal dari berbagai kota.

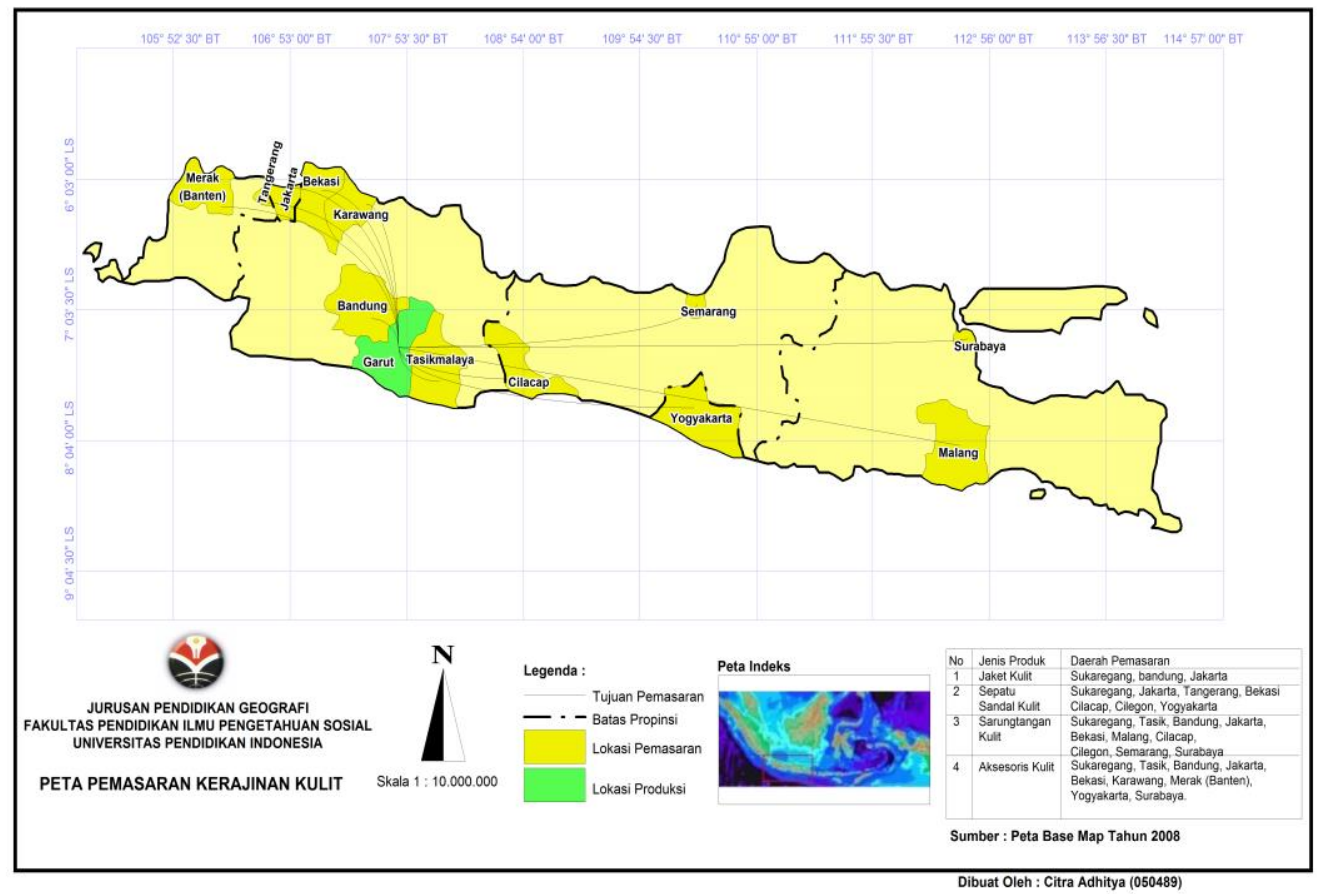




\section{Analisis Konsentrasi Industri Barang Kerajinan Kulit dan Hasil Korelasi Variabel Penelitian}

Konsentrasi industri kulit di Kabupaten Garut tersebar di dua kecamatan yaitu Kecamatan Garut Kota dan Karangpawitan. Konsentrasi industri kulit di dua kecamatan tersebut terdapat di beberapa desa, tetapi konsentrasi secara besar-besaran terjadi di daerah Sukaregang dan sekitarnya. Adapun keterangan lebih lanjut daerah konsentrasi industri kulit di Kabupaten Garut dapat dilihat pada tabel 7.

Tabel 7. Daerah Konsentrasi Industri Kulit di Kabupaten Garut

\begin{tabular}{|c|c|c|c|c|}
\hline No & Kecamatan & Kelurahan/Desa & $\begin{array}{c}\text { Jumlah } \\
\text { Unit Usaha }\end{array}$ & $\%$ \\
\hline 1. & Garut Kota & Kel. Cimuncang & 2 & 0,75 \\
\hline 2. & Garut Kota & Kel. Sukamentri & 7 & 2,64 \\
\hline 3. & Garut Kota & Kel. Kota Wetan & 115 & 43,40 \\
\hline 4. & Karangpawitan & Ds. Jatisari & 12 & 4,53 \\
\hline 5. & Karangpawitan & Ds. Lebakjaya & 2 & 0,75 \\
\hline 6. & Karangpawitan & Ds. Suci & 49 & 18,49 \\
\hline 7. & Karangpawitan & Ds. Lengkongjaya & 43 & 16,23 \\
\hline 8. & Karangpawitan & Ds. Lebak Agung & 5 & 1,89 \\
\hline 9. & Karangpawitan & Ds. T anjungsari & 1 & 0,38 \\
\hline 10. & Karangpawitan & Ds. Karangmulya & 29 & 10,94 \\
\hline \multicolumn{3}{|c|}{ Jumlah } & 265 & 100,00 \\
\hline
\end{tabular}

Sumber: Dinas Perindustrian, Perdagangan, dan Penanaman Modal Kab.Garut 2008 Monografi Kecamatan Garut Kota dan Karangpawitan, Kab. Garut 2008

Konsentrasi industri kulit terbesar terjadi di Kelurahan Kota Wetan dilanjutkan dengan Desa Suci yang menduduki daerah konsentrasi ke dua dengan selanjutnya Desa Lengkongjaya yang merupakan daerah ke tiga konsentrasi industri kulit dan diikuti dengan daerah-daerah lainnya yang memiliki konsentrasi unit usaha yang lebih kecil. Adapun tabel 8 dan Peta Konsentrasi Industri Kulit di Wilayah Sampel Penelitian beserta analisisnya disajikan sebagai berikut.

Tabel 8. Titik Sampel Konsentrasi Industri Kulit di Wilayah Sampel Penelitian

\begin{tabular}{lllll}
\hline \multicolumn{1}{c}{ Wilayah Sampel } & \multicolumn{3}{c}{ Lokasi Industri } \\
\hline Kelurahan Kota Wetan & 1. & Kp.Sukaregang RT 04/RW12 & \\
& 2. & Kp.Sukaregang RT 01/RW14 & \\
& 3. & Kp.Sukaregang & Kidul & RT \\
& & 04/RW21 & & \\
& 4. & Kp Sukaregang RT 03/ RW 14 \\
& 5. & Kp Sukaregang RT 01/ RW 21 \\
& 6. & Kp Sukaregang RT 02/ RW21 \\
& 7. & Jalan Gagak Lumayung No 222 \\
& 8. & Jalan Gagak Lumayung No 29 \\
\hline
\end{tabular}




\begin{tabular}{lll}
\hline & 9. & Jalan Gagak Lumayung No 52 \\
& 10. Jalan Gagak Lumayung No.1036 \\
& 11. Jalan Ahmad Yani No.242 A/264 \\
& 12. Jalan Ahmad Yani No 317 \\
\hline Desa Karangmulya & 1. & Kp Karang Tengah RT 03/ RW 06 \\
& 2. & Kp.Karangmulya RT02/RW08 \\
& 3. & Kp.Cibangban RT03/RW03 \\
& 4. & Kp Cibangban RT02/ RW10 \\
& 5. & Kp Cibangban RT 01/RW 03 \\
\hline Desa Lebak Agung & 1. & Kp. Kp.Lebak Agung RT03/RW03 \\
& 2. & Kp.Lebak Agung RT01/RW03 \\
& 3. & Kp.Cipondok RT01/RW05 \\
\hline
\end{tabular}

Sumber: Hasil Penelitian 2009

Konsentrasi industri kulit di wilayah penelitian, di analisis dengan menggunakan teknik analisa tetangga terdekat, hal ini dikarenakan teknik analisa tetangga terdekat sangat tepat jika digunakan di daerah atau wilayah yang tidak memiliki hambatan morfologi dan topografi wilayah. Analisa tetangga terdekat digunakan untuk mengukur konsentrasi industri kulit di wilayah penelitian, apakah bergerombol atau tersebar. Adapun sampel yang digunakan untuk analisa tetangga terdekat dalam penelitian ini adalah 20 sampel lokasi penelitian yang tersebar pada dua kecamatan dan tiga desa, yang memiliki jarak bervariasi dengan titik tetangga terdekatnya. Jumlah keseluruhan jarak garis lurus antar tetangga terdekatnya adalah 8,4632 km yang didapat berdasarkan penarikan jarak lurus dari peta wilayah dengan skala 1 : 75.000. Mengacu kepada hasil perhitungan analisa tetangga terdekat untuk industri kulit diatas, diperoleh angka persebarannya sebesar 0,69199842. Dengan demikian, angka tersebut menunjukkan pola konsentrasi yang mengelompok.

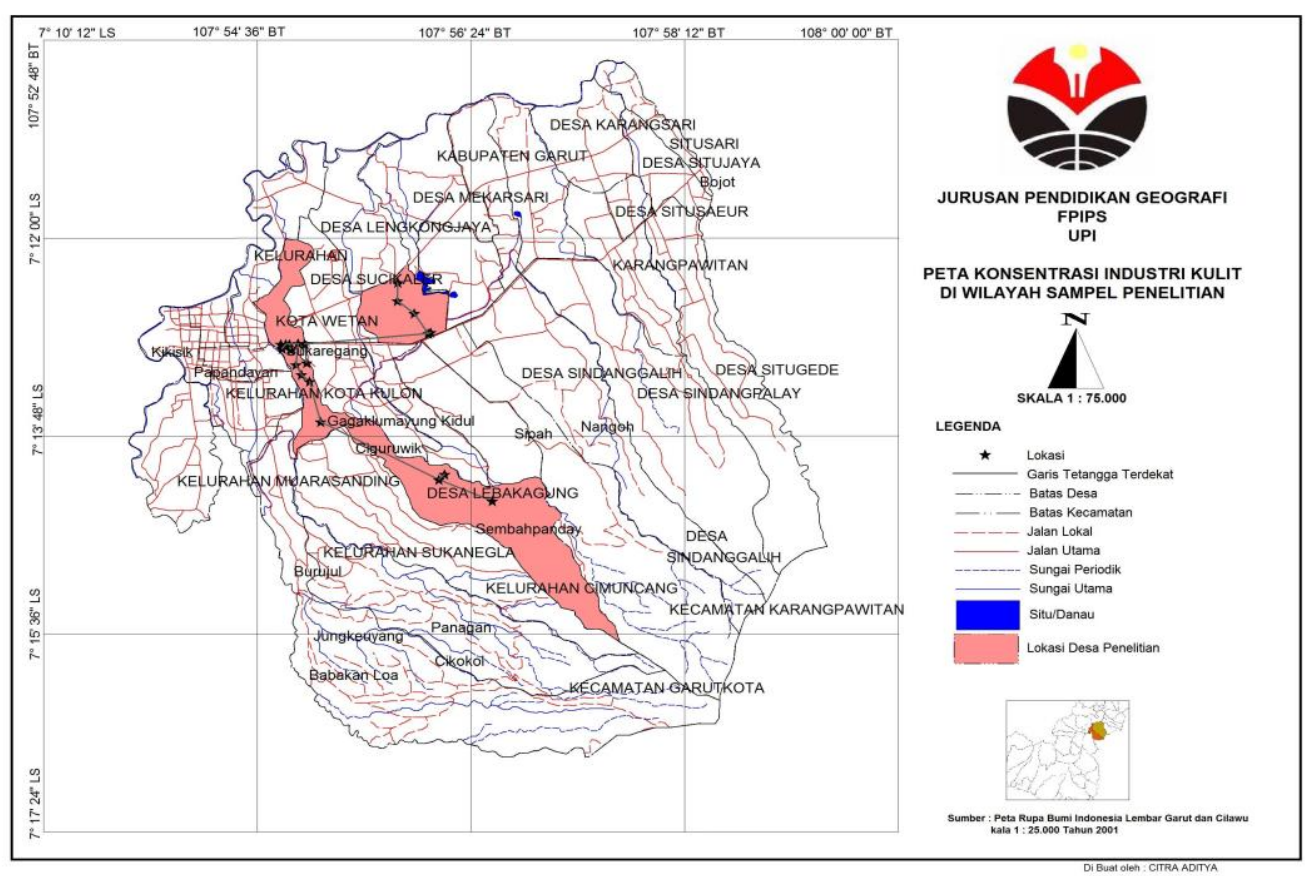


Gambar 3. Peta Konsentrasi Industri Kulit di Wilayah Sampel Penelitian

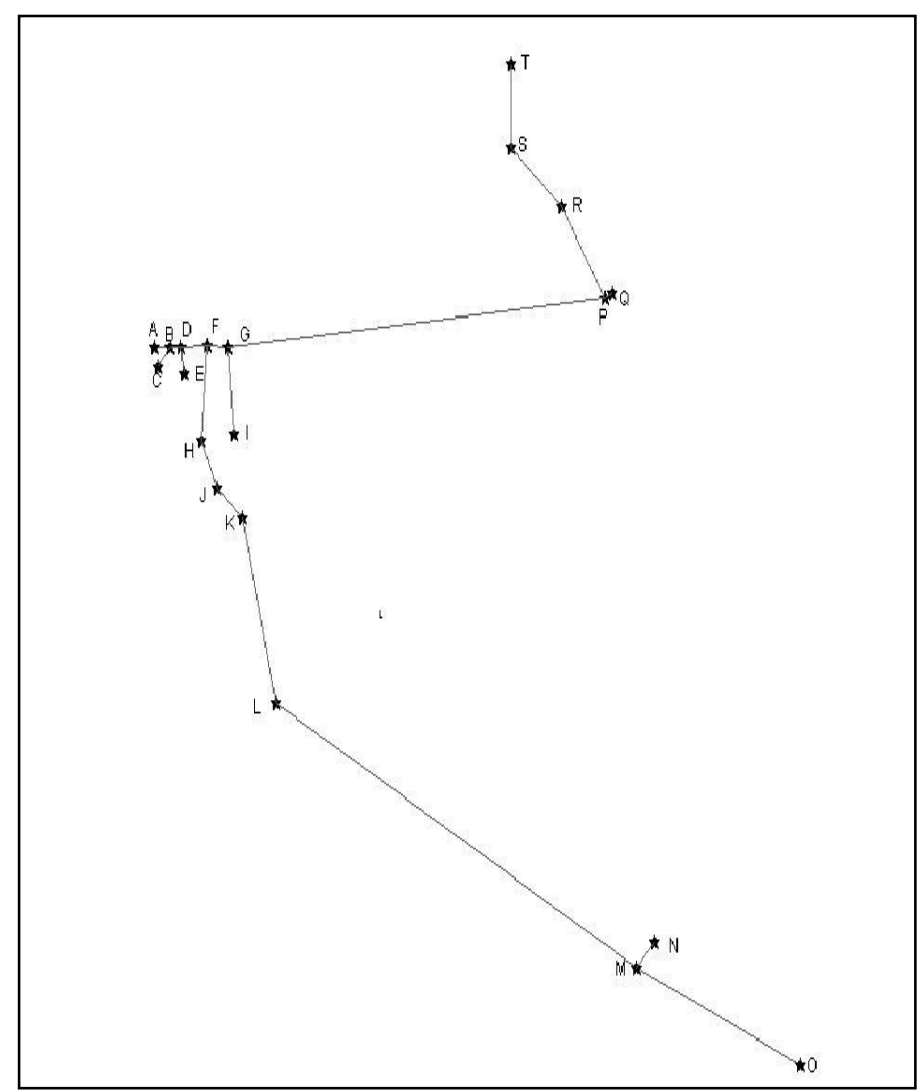

Gambar 4. Posisi Kode Wilayah Titik Sampel

\section{Hubungan Ketersediaan Bahan Baku dengan Faktor Lokasi Industri}

Lokasi suatu industri di suatu daerah dapat dipengaruhi oleh ketersediaan bahan baku di daerah tersebut. Korelasi antara ketersediaan bahan baku dengan lokasi industri menunjukkan hubungan yang cukup berarti atau sedang. Kondisi ini disebabkan karena ketersediaaan bahan baku untuk industri kulit yang berada di Kota Wetan relatif banyak dan mecukupi. Hal ini dikarenakan bahan baku banyak diproduksi di daerah Sukaregang, Kelurahan Kota Wetan, Kecamatan Garut Kota. Selanjutnya lokasi industri barang kerajinan kulit menyebar di beberapa desa di Kecamatan Garut Kota dan Karangpawitan. Desa-desa yang berdekatan dengan Sukaregang pada umumnya mengambil bahan baku di daerah tersebut, sehingga bahan baku relatif banyak. Selain itu, ada beberapa pengusaha kulit di desa tertentu seperti Karangmulya yang mendatangkan bahan baku dari luar kota, seperti Jakarta, Tangerang dan Bekasi sehingga ketersediaan bahan baku di daerah tersebut ditentukan oleh pengiriman dari pemasok luar kota. Adakalanya ketersediaan bahan 
baku di Karangmulya mengalami penurunan secara kuantitas. Jadi dapat ditarik kesimpulan bahwa ketersediaan bahan baku relatif banyak bila lokasi industri dekat dengan wilayah Sukaregang.

Pola hubungan antara ketersediaan bahan baku dengan jarak sumber bahan baku ke lokasi industri menunjukkan hubungan yang cukup berarti atau sedang. Hal ini disebabkan karena sebagian besar dari pengusaha yang mengambil bahan baku dengan jarak $>500 \mathrm{~m}$ dan antara 500-1 km memiliki tingkat ketersediaan bahan baku yang banyak. Adapun daerah sumber bahan baku dengan jangkauan jarak 500m-1km yaitu berpusat di Sukaregang. Sedangkan lokasi industri dengan jarak antara $1-3 \mathrm{~km}$ merupakan industri yang letaknya bertetangga dengan daerah Sukaregang. Jadi semakin dekat lokasi industri dengan daerah sumber bahan baku maka ketersediaan bahan baku semakin banyak.

Sedangkan pola hubungan antara ketersediaan bahan baku dengan biaya transportasi menunjukkan tingkatan yang cukup berarti atau sedang. Hal ini disebabkan karena sebagian pengusaha yang tidak mengeluarkan biaya transportasi dan yang mengeluarkan biaya transportasi antara $10.000-25.000$ memiliki tingkat ketersediaan bahan baku yang relati banyak. Pengusaha kulit yang tidak mengeluarkan ongkos pada umumnya berlokasi di sekitar daerah Sukaregang dengan tingkat ketersediaan bahan baku yang banyak. Sebagian besar industri yang berada di Karangmulya mengeluarkan biaya pengiriman bahan baku karena bahan baku di datangkan dari luar kota seperti Jakarta, Tangerang dan Bekasi. Ketersediaan bahan baku di Karangmulya ditentukan oleh pengririman bahan baku dari luar kota.

\section{Hubungan Ketersediaan Tenaga Kerja dengan Faktor Lokasi Industri}

Ketersediaan tenaga kerja dapat mempengaruhi lokasi industri. Banyaknya tenaga kerja serta upah tenaga kerja yang murah dapat memicu suatu industri didirikan di daerah tersebut. Ketersediaan tenaga kerja dengan lokasi industri memiliki hubungan yang rendah atau lemah tetapi pasti. Hal ini disebabkan karena ketersediaan tenaga kerja di setiap lokasi industri hampir sebagian banyak. Tetapi suatu waktu bisa terjadi kekurangan ketersediaan tenaga kerja di setiap lokasi industri apabila terjadi permintaan produk secara tiba-tiba dari pihak konsumen, sehingga ketersediaan tenaga kerja tidak terlalu ditentukan oleh lokasi suatu industri.

Bila dihubungkan antara jarak dengan ketersediaan tenaga kerja maka diperoleh suatu hubungan yang cukup berarti atau sedang. Hal ini terjadi karena tenaga kerja banyak tersedia dengan jarak > 500meter dari lokasi industri. Hal ini berarti bahwa pada umumnya pengusaha industri kulit merekrut tenaga kerja yang berasal dari daerah lingkungan sekitar industri. Pola hubungan antara ketersediaan tenaga kerja dengan biaya transportasi tenaga kerja memiliki hubungan yang cukup berarti atau sedang. Hal ini terjadi karena banyak tenaga kerja di daerah lingkungan sekitar industri sehingga sebagian besar tenaga kerja tidak mengeluarkan biaya trasportasi untuk sampai ke tempat kerja. Kondisi ini terjadi di daerah Kota Wetan, Karangmulya dan Lebak Agung. 


\section{Hubungan Daerah Pemasaran dengan Faktor Lokasi Industri}

Selain bahan baku dan tenaga kerja ada faktor lain yang menentukan lokasi suatu industri yaitu pemasaran. Lokasi pemasaran yang dekat bisa saja menjadi bahan pertimbangan bagi seorang pengusaha untuk mendirikan industri di daerah tersebut. Hubungan antara daerah pemasaran dengan lokasi industri memiliki hubungan yang rendah atau lemah tapi pasti. Hal ini terjadi karena cakupan daerah pemasaran banyak dilakukan di luar provinsi dan sebagian lagi dipasarkan ke kota-kota lain yang masih satu provinsi. Bahkan ada sebagian pengusaha barang kerajinan kulit yang telah berhasil memasarkan produknya ke pasaran internasional. Jadi dearah pemasaran telah meluas dan tidak hanya dilakukan di lokasi industri. Adapun daerah pemasaran barang kerajinan kulit secara lokal berpusat di Gagak Lumayung, Sukaregang yang termasuk ke dalam kawasan Kelurahan Kota Wetan, Kecamatan Garut Kota.

Pola hubungan antara daerah pemasaran dengan jarak pemasaran yaitu memiliki hubungan yang tinggi atau kuat. Sebagian pengusaha memilki jarak > 100 $\mathrm{km}$ dari lokasi industri dikarenakan jangkauan daerah pemasarannya luar provinsi. Jadi dapat ditarik kesimpulan bahwa semakin luas cakupan daerah pemasaran maka semakin tinggi jarak yang harus ditempuh.

Hubungan antara derah pemasaran dengan biaya transportasi memiliki hubungan yang yang rendah atau lemah tapi pasti. Hal ini terjadi dikarenakan meskipun produk barang kerajinan kulit dipasarkan ke luar propinsi tetapi biaya transportasi pemasaran terbilang minim karena ongkos angkut pada umumnya ditanggung oleh pemasok dari luar kota. Selain itu ada pengusaha industri kulit yang menggunakan jasa pengiriman sehingga biaya pemasaran lebih ditentukan oleh kuantitas dan intensitas pengiriman barang tersebut.

\section{SIMPULAN}

Kesimpulan yang dapat diambil dari penelitian yang telah dilakukan adalah bahwa konsentrasi industri kulit secara besar-besaran terjadi di Sukaregang, Kecamatan Garut Kota, Kabupaten Garut. Adapun tingkat konsentrasi industri yang ada di Kabupaten Garut yaitu sebesar 0,69199842 yang menunjukkan pola mengelompok dari penyebaran industri yang ada. Adanya konsentrasi dikarenakan faktor bahan baku yang mendukung di kawasan Sukaregang yang merupakan pusat penyamakan kulit terbesar di Kabupaten Garut. Bahan baku kulit yang telah mengalami penyamakan mudah didapatkan di daerah tersebut. Kenyataan ini diperkuat oleh adanya tingkat korelasi sebesar 0,473 yang menghubungkan antara ketersediaan bahan baku dengan lokasi industri yang ada di Kota Wetan, Karangmulya dan Lebak Agung. Berdasarkan hal tersebut maka pengrajin kulit yang berlokasi di Kelurahan Kota Wetan memiliki ketersediaan bahan baku yang banyak dan mendapatkan bahan baku dengan jarak terdekat bila dibandingkan dengan Desa Karangmulya maupun Lebak Agung. 
Selain faktor bahan baku terdapat faktor geografis lainnya yang menentukan lokasi industri di Kabupaten Garut seperti tenaga kerja, dan pemasaran. Lokasi industri tidak terlalu berpengaruh terhadap ketersediaan tenaga kerja. Hal ini diperkuat dengan hubungan antar variabel tersebut sebesar 0,245 yang menunjukkan pola hubungan yang lemah. Ketersediaan tenaga kerja pada umumnya dipengaruhi oleh banyaknya permintaaan produk di pasaran..

Pemasaran produk kerajinan kulit pada umumnya dipasarkan ke kota-kota luar provinsi. Bahkan ada sebagian pengusaha kerajinan kulit yang telah berhasil memasarkan produknya ke pasaran imternasional. Berdasarkan hal tersebut maka didapat korelasi yang lemah antara daerah pemasaran dengan lokasi industri sebesar 0,226 . Selain itu daerah pemasaran barang kerajinan kulit secara lokal berpusat di Gagak Lumayung, Sukaregang yang termasuk ke dalam kawasan Kelurahan Kota Wetan, Kecamatan Garut Kota.

Beberapa rekomendasi yang dapat dikemukakan oleh penulis yaitu:

1) Bagi para pengrajin kulit hendaknya meningkatkan barang kerajinan kulit dari segi kualitas maupun kuantitas serta membuat inovasi barang kerajnan kulit agar dapat memiliki daya saing yang tinggi baik itu di pasaran nasional maupun internasional. Apabila pengrajin kulit menemukan kendala dalam usaha hendaknya dikomunikasikan kepada instansi terkait, dalam hal ini Dinas Perindustrian dan Perdagangan yang menjadi wadah untuk menampung dan memberikan pencerahan bagi permasalahan yang dihadapi oleh pengrajin kulit di Kabupaten Garut.

2) Bagi instansi terkait terutama Dinas Perindustrian dan Perdagangan agar dapat memberikan perhatian lebih serius bagi permasalahan yang dihadapi oleh para pengrajin kulit supaya perkembangan industri ini semakin meningkat dari segi kualitas maupun kuantitas.

3) Bagi yang tertarik untuk meneliti lebih lanjut tentang industri kulit di Kabupaten Garut semoga penelitian ini dapat menjadi rujukan.

\section{DAFTAR PUSTAKA}

Abdurachmat, Idris dan Maryani, E. (1998). Geografi Ekonomi. Bandung: Jurusan Pendidikan geografi FPIPS IKIP Bandung.

Arikunto, Suharsimi. (2002). Prosedur Penelitian Suatu Pendekatan Praktek. Jakarta: Rineka Cipta.

Biro Pusat Statistik (2009). Kabupaten Garut Tahun 2008. Garut: BPS.

Bintarto, R. (1982). Metode Analisis Geografi. Jakarta: LP3ES.

Daldjoeni. (1997). Geografi Baru Organisasi keruangan dalam Teori dan Praktek. Bandung: Alumni.

Daldjoeni. (1992). Geografi Desa dan Kota. Bandung: Rineka Cipta.

Djojodiputro, Marsudi. (1992). Teori Lokasi. Jakarta: Lembaga Penerbit FE UI.

Hasan, Iqbal. (2006). Analisis Data Penelitian dengan Statistik. Jakarta: Bumi Aksara 
Kotler, Philip dan Keller, Kevin Lane. (2002). Manajemen Pemasaran edisi 12 jilid 1. Jakarta: Indek.

Kuncoro, Mudrajad. (2002). Analisis Spasial dan Regional Aglomerasi dan Kluster Industri Indonesia. Yogyakarta: UPP AMP YPKN.

Rafi'i, Suryatna. (1995). Meteorologi dan Klimatologi. Bandung: Angkasa.

Sandi, I Made. (1986). Geografi Regional Indonesia. Jakarta: UI Pressto.

Sugiyono. (2006). Statistika Untuk Penelitian. Bandung: Alfabeta.

Sumaatmadja, Nursid. (1981). Studi Geografi: Suatu Pendekatan dan Analisa Keruangan. Bandung: Alumni.

Tika, Pabundu. (2005). Metode Peneliitian Geografi. Jakarta:Bumi Aksara. 